\title{
Kosakata Serapan Bahasa Minangkabau dari Bahasa Arab (Analisis Morfofonologi-Semantik)
}

\author{
Isnaini Rahmawati \\ Universitas Islam Negeri Raden Fatah Palembang
}

\begin{abstract}
Abstrak
Penelitian ini mencoba mencari tahu tentang bagaimana perubahan secara fonemis pembentukan kosakata serapan bahasa Arab dalam bahasa Minangkabau (Padang, Sumatera Barat). Kemudian adakah perubahan makna yang terjadi dengan adanya proses fonologi dan morfologi terhadap kosakata serapan bahasa Minang dari Bahasa Arab. Peneliti menggunakan metode agih dalam menganalisis data. Metode agih menurut Sudaryanto adalah metode analisis yang alat penentunya terdapat pada bahasa itu sendiri, dengan cara substitusi. Metode agih digunakan untuk menentukan pergeseran kata Bahasa Arab dalam bahasa Minangkabau. Selanjutnya dalam menganalisis hasil penelitian, penulis melibatkan dua bahasa; dengan demikian, penelitian ini juga menggunakan metode padan translasional. Pada tataran fonologis kosakata serapan bahasa Minang yang terambil dari bahasa Arab, beberapa fonem bisa diserap secara utuh dalam artian sesuai dengan transliterasi Arab-latin, namun ada juga yang tidak diserap secara utuh seperti fonem $\dot{ }$, karena fonem ini bukan diserap dengan menggunakan fonem /f/ dalam bahasa Minang namun diserap dengan /p/. Pada tataran morfologis dan semantik, beberapa perbedaan ditemukan antara bahasa Arab dan bahasa Minang. Sekalipun kosakata serapan bahasa Minang tersebut diambil dari bahasa Arab, namun urutan huruf dan kata terkadang tidak serupa. Begitu pula mengenai makna kata dalam bahasa Minang yang merupakan serapan dari bahasa Arab mengalami penyempitan dan perluasan, namun tidak sedikit juga yang tidak mengalami perubahan makna.
\end{abstract}

Kata Kunci: Kosakata Serapan, Fonologi, Morfologi, Bahasa Arab

\section{Pendahuluan}

Penyebaran agama Islam ke Indonesia, termasuk ke ranah Minang, banyak mempengaruhi pikiran, perasaan, tingkah laku, dan segala aspek kehidupan masyarakat Minangkabau. Kosakata yang berasal dari Bahasa Arab juga banyak masuk ke dalam perbendaharaan bahasa Minangkabau, yang selanjutnya dikenal dengan sebutan kosakata serapan yakni kosakata yang diserap dari bahasa lain. ${ }^{1}$

${ }^{1} \mathrm{KBBI}$, hlm. 1046 
Dalam Bahasa Minang terdapat empat ragam bahasa, yang mempengaruhi dan sangat bergantung pada situasi dan kondisi pada saat bahasa tersebut dipergunakan. Keempat ragam bahasa tersebut, antara lain: ${ }^{2}$ ragam bahasa adat, ragam bahasa surau, ragam bahasa parewa, ragam bahasa biasa. Ragam bahasa surau adalah ragam bahasa yang kosakatanya banyak diserap dari bahasa Arab.

Penyerapan bahasa terjadi karena adanya kontak berkelanjutan dalam waktu lama antar penutur bahasa. Menurut Mackey ketika kontak itu terjadi, maka kedua pengguna bahasa saling memengaruhi satu sama lain. Bahasa yang menerima pengaruh disebut model, dan bahasa yang dipengaruhi disebut donor. Proses ketika donor memengaruhi model disebut borrowing atau penyerapan. ${ }^{3}$ Proses penyerapan antar bahasa yang membentuk kata baru mempengaruhi adanya perubahan makna. Hal itu dikarenakan perbedaan budaya dan kebiasaan masingmasing negara. Pembentukan kata yang diambil dari bahasa satu ke bahasa lainnya memerlukan waktu lama yang akhirnya menimbulkan pergeseran makna. Selain bagaimana proses pembentukan kata, kajian tentang makna juga akan dilakukan, karena pada hakikatnya kata dan makna adalah satu kesatuan.

\section{Rumusan Masalah}

Berdasarkan pada latar belakang yang telah dipaparkan sebelumnya maka rumusan masalahnya adalah sebagai berikut :

a. Bagaimana perubahan fonem dalam kosakata serapan Bahasa Arab dalam bahasa Minangkabau (Padang, Sumatera Barat) ?

b. Adakah perubahan makna yang terjadi pada kata serapan bahasa Minangkabau dari Bahasa Arab yang melalui proses morfologis?

c. Apa saja perubahan makna yang terjadi dengan adanya proses penyerapan dari Bahasa Arab ke dalam bahasa Minangkabau?

\section{Metode Penelitian}

\subsection{Metode Penyediaan Data}

Dalam menyediakan data, peneliti menggunakan metode analisis deskriptif kualitatif. Analisis deskriptif adalah suatu metode dengan jalan mengumpulkan data, menyusun atau mengklasifikasi, menganalisis, dan menginterpretasikannya. ${ }^{4}$ Sedangkan menurut Surakhman metode deskriptif adalah: "Metode penelitian yang dalam pelaksanannya tidak terbatas hanya sampai pengumpulan data saja, melainkan meliputi analisis dan interpretasi tentang arti data". 5

\footnotetext{
${ }^{2} \mathrm{Http} / /$ :Perbedaan Bahasa Antar Daerah di Sumber dan Perbedaannya dengan Bahasa Melayu__Asrama Mahasiswa Sumatera Barat.html, diakses tanggal17 Desember 2014

${ }^{3}$ William F. Mackey, The Description of Billingualism, dalam Joshua A. Fishman (ed), Reading in the Sociology of anguage, The Hauge: Mouton \& Company, 1968, hal. 554

${ }^{4}$ Moh. Nasir, Metode Penelitian, dalam Buletin Al-Turas Mimbar Sejarah,Sastra,Budaya, dan AgamaVol. XXIII No.2, Juli 2017

${ }^{5}$ Winarno, Surakhmand. Pengantar Penelitian Ilmiah. Bandung: Tarsito, 1980, hlm. 31
} 
Dalam pelaksanaannya, penelitian ini menggunakan: (1) teknik simak dan catat, (2) teknik pustaka, yaitu data diperoleh dari sumber-sumber tertulis. Sumber yang digunakan berupa data primer dan data sekunder: Kamus Minangkabau-Indonesia, Pusat Pembinaan dan Pengembangan Bahasa Departemen Pendidikan dan Kebudayaan Jakarta 1985, sebagai data primer, sedangkan untuk data sekunder diambil dari berbagai kamus bahasa Arab untuk mengetahui makna kata.

Adapun tahapan dari penelitian ini adalah (1) Mengumpulkan dan mengidentifikasi data-data serta literatur yang berhubungan dengan kosakata serapan dalam bahasa Minangkabau, (2) Membaca dan memahami buku-buku bahan referensi lainnya yang berkaitan dengan pembentukan kata, dan (3) Menganalisis data yang telah diperoleh sebagai hasil laporan awal lalu menyusunnya kembali secara sistematis dalam bentuk laporan akhir.

\subsection{Metode Analisis Data}

Peneliti memilih menggunakan metode agih dalam menganalisis data. Metode agih menurut Sudaryanto adalah metode analisis yang alat penentunya terdapat pada bahasa itu sendiri, dengan cara substitusi. ${ }^{6}$ Metode agih digunakan untuk menentukan pergeseran kata Bahasa Arab dalam bahasa Minangkabau. Selanjutnya dalam menganalisis hasil penelitian, penulis melibatkan dua bahasa; dengan demikian, penelitian ini juga menggunakan metode padan translasional.

Sudaryanto menyebutkan, metode padan adalah metode yang dipakai untuk mengkaji atau menentukan identitas satuan diagonal dengan memakai alat penentu yang berada di luar bahasa. Alat penentunya adalah segala sesuatu yang ditunjuk bahasa (referent), alat ucap pembentuk bunyi bahasa (tulisan), bahasa lain dan lawan bicara untuk kebutuhan penelitian. ${ }^{7}$ Metode padan ini digunakan untuk memadankan unsur-unsur teranalisis, yakni katakata serapan dari Bahasa Arab yang terdapat dalam Bahasa Minangkabau dengan alat penentu kata asalnya dalam Bahasa Arab.

\section{Pembahasan}

\subsection{Kasus Fonologi Penyerapan Bahasa Arab ke dalam Bahasa Minang}

Menurut Muslich, fonologi adalah kajian yang mendalami bunyibunyi ujar. ${ }^{8}$ Selanjutnya Clark dan Yallop berpendapat bahwa fonetik merupakan bidang yang berkaitan erat dengan kajian bagaimana cara manusia

\footnotetext{
${ }^{6}$ Dwi Haryanti, Indonesia. Edisi Februari 2007, Tahun ke 25, Nomor 1. Yayasan Obor Indonesia. 2007

${ }^{7}$ Sudaryanto. Metode dan Aneka Teknik Analisis Bahasa, 1993, Yogyakarta: Duta Wacana University Press, hlm. 2

${ }^{8}$ Masnur Muslich. (2008). KTSP Pembelajaran Berbasis Kompetensi dan Kontekstual. Jakarta: Bumi Aksara, hlm. 1
} 
berbahasa serta mendengar dan memproses ujaran yang diterima ${ }^{9}$. Setelah melakukan pengamatan dan pengkajian terhadap kosakata serapan bahasa Minang dari bahasa Arab, ditemukan beberapa penyesuaian fonem-fonem Arab terhadap fonem-fonem dalam bahasa Minang:

1) Fonem ب

Di dalam sistem transliterasi Arab-Latin, fonem $ب$ di dalam bahasa Arab ditransliterasi menjadi /b/. Oleh karena itu, di dalam sistem fonem yang berlaku, fonem /b/ dipertahankan.

\begin{tabular}{|c|c|c|}
\hline Posisi Awal & Tengah & Akhir \\
\hline Balig (بالغ) & Ibaraik (عبارة) & Azab (عذاب) \\
\hline Barakaik (بركة) & Ibilih (ابليس) & Gaib (غائب) \\
\hline Batal (بطل-يبطل) & Katubah (خطبة) & Ijab (اجاب) \\
\hline
\end{tabular}

Pada kolom pertama, tampak bahwa fonem /b/ pada posisi awal tidak mengalami perubahan, yaitu tetap menjadi fonem $/ \mathrm{b} /$. Demikian pula pada posisi tengah, seperti yang terlihat dalam kata ibaraik, ibilih dan seterusnya, fonem /b/ tidak mengalami perubahan. Namun di posisi akhir, ada beberapa fonem /b/ yang mengalami perubahan seperti kata katib dan mugarik.

2) Fonem $ت$

Fonem $ت$ di dalam bahasa Arab ditranslierasi menjadi /t/.

\begin{tabular}{|c|c|c|}
\hline Posisi Awal & Tengah & Akhir \\
\hline Taalia (تهليل) & Fatwa (فنتي) & Barakaik (بركة) \\
\hline Tadaruih (تدرس) & Mufti (مفتي) & Ibaraik (عبارة) \\
\hline Tahmid (تحميد) & Pitnah (فتنتة) & Isaraik (اشارة) \\
\hline
\end{tabular}

Fonem /t/ pada posisi awal seperti pada kata tadaruih, tahmid dan seterusnya ditulis dengan /t/ tanpa ada perubahan begitu pula pada posisi tengah seperti fatwa, mufti, namun di posisi akhir ada beberapa fonem $ت$ tidak berbunyi t seperti barakaik, ibaraik, dan seterusnya dalam tabel di atas.

3) Fonem ج

Fonem ج ditransliterasikan menjadi /j/. Di dalam penyerapan kata Arab ke dalam bahasa Minang, fonem ini tidak mengalami perubahan.

\begin{tabular}{|c|c|c|}
\hline Posisi Awal & Tengah & Akhir \\
\hline Jamaah (جماعة) & Fajar (فجر) & \\
\hline Jamaik (الجمعة) & Ijab (اجاب) & \\
\hline Janazah (جنازة) & Musajik (مسجد) & \\
\hline
\end{tabular}

Dalam kamus bahasa Minangkabau-Indonesia yang menjadi sumber kosakata bahasa Minang pada penelitian ini, ditemukan beberapa fonem /j/ yang berada di posisi awal dan tengah. Fonem /j/

${ }^{9}$ Amril dan Ermanto. 2007. Fonologi. Bahasa Indonesia. Padang: UNP, hlm. 8-9 
dalam kosakata serapan seperti dalam tabel di atas, terlihat bahwasanya fonem /j/ tidak mengalami perubahan baik ketika ia berada di awal kata seperti kata jamaah, jamaik, janazah dan seterusnya maupun di tengah kata seperti fajar, ijab, musajik dll.

4) Fonem $\dot{\tau}$

Fonem ini ditransliterasi menjadi /k/ dalam bahasa Minang. Hal ini berbeda dengan bahasa Indonesia yang menuliskan fonem $\dot{\tau}$ menjadi /kh/.

\begin{tabular}{|l|l|l|}
\hline Posisi Awal & Tengah & Akhir \\
\hline Katik (خاطب) (خطبة) (خمبس) & Mukaluak & \\
Katubah & & \\
Kamih & & \\
\hline
\end{tabular}

Pada data di atas tampak fonem / $\dot{\tau} /$ mengalami perubahan menjadi $/ \mathrm{k} /$, baik pada posisi awal, seperti kata katik dan katubah maupun pada posisi tengah, seperti kata mukaluak.

5) Fonem د

Fonem د dalam bahasa Arab ditranskrip menjadi /d/. Dalam penyerapannya ke bahasa Minang tidak mengalami perubahan kecuali di posisi akhir pada kata-kata tertentu, seperti dalam tabel berikut:

\begin{tabular}{|c|c|c|}
\hline Posisi Awal & Tengah & Akhir \\
\hline Dalil (دليل) & Akidah (عقيدة) & Akad (عقد) \\
\hline Doa (دعاء) & Bidaah (بدعة) & Jilik (جلد-يجلد) \\
\hline Duia (دنيا) & Madrasah (مدرسة) & Mukasuik (مقصد) \\
\hline
\end{tabular}

Berdasarkan contoh di atas, diketahui bahwa fonem /// tetap ditulis /d/, dalam penyerapannya, baik pada posisi awal, seperti kata dalil, doa dan dunia, begitupun pada posisi tengah, seperti kata akidah, bidaah, akan tetapi pada posisi akhir ada yang mengalami perubahan seperti kata jilik, berubah menjadi /k/.

6) Fonem $\lrcorner$

Fonem $\lrcorner$ dalam bahasa Arab ditranskrip menjadi /r/. Beberapa kasus dalam kosakata serapan bahasa Minang dari bahasa Arab yang di dalamnya terdapat fonem $J$ tidak mengalami perubahan namun ada beberapa juga yang berubah, dalam artian tidak ditulis maupun dilafalkan dengan fonem $/ \mathrm{r} /$.

\begin{tabular}{|c|c|c|}
\hline Posisi Awal & Tengah & Akhir \\
\hline Rabaa (الاربعاء) & Almahum (المحروم) & Asar (عصر) \\
\hline Rahim (رحيم) & Aram (حرام) & Kapia (كافر) \\
\hline Rasua (رسول) & Arawah (ارواح)) & Saba (صبر) \\
\hline
\end{tabular}


Seperti yang dapat dilihat pada contoh di atas, fonem /r/ tidak mengalami perubahan, pada posisi awal, seperti kata rabaa dan rahim, pada posisi tengah, seperti kata arif dan jariah namun bisa dilihat ada kosakata serapan dalam bahasa Minang berupa kata almahum yang mana fonem /r/ pada kata ini tidak dilafakan maupun dituliskan atau bisa dibilang dihilangkan. Selain itu pada posisi akhir, fonem /r/ ada juga yang tidak dilafalkan seperti kata saba.

7) Fonem $j$

Fonem $j$ ditranskrip menjadi /z/. Dalam serapan bahasa dari bahasa Arab, fonem $j$ tidak mengalami perubahan, yakni tetap ditulis dengan /z/.

\begin{tabular}{|l|l|l|}
\hline Posisi Awal & Tengah & Akhir \\
\hline Zaman (زنازة) & Janazah $(j$ (زيارة) & \\
Ziarah & & \\
\hline
\end{tabular}

Berdasarkan data di atas terlihat fonem $j$ diserap dengan mentranskripkannya menjadi huruf /z/ baik itu di posisi awal seperti zaman dan ziarah maupun di tengah yang berupa kosakata serapan janazah.

8) Fonem w

Fonem wdalam bahasa Arab ditranskrip menjadi /s/.

\begin{tabular}{|c|c|c|}
\hline Posisi Awal & Tengah & Akhir \\
\hline $\begin{array}{l}\text { Sabab (سبب) (سبت) } \\
\text { Sabtt }\end{array}$ & $\begin{array}{l}\text { Kurisi (كرسي) } 1 \text { (مدرس) } \\
\text { Madrasah }\end{array}$ & $\begin{array}{l}\text { Ibilih (ابليس) } \\
\text { Kamih خمبس) }\end{array}$ \\
\hline
\end{tabular}

Dalam kolom pertama $s a b a b$, fonem /s/ yang terdapat pada posisi awal tidak mengalami perubahan dari fonem aslinya dan demikian pula pada posisi tengah. Namun di posisi akhir fonem /s/ mengalami perubahan menjadi $/ h /$.

9) Fonem ش

Fonem ش dalam bahasa Arab dalam proses penyerapannya ke dalam bahasa Minang ada yang ditransliterasi menjadi /sy/ namun lebih banyak yang hanya mentransliterasikannya menjadi /s/. Seperti nampak pada contoh berikut:

\begin{tabular}{|c|c|c|}
\hline Posisi Awal & Tengah & Akhir \\
\hline 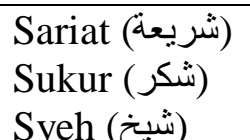 & $\begin{array}{l}\text { Isaraik (اششارة) } \\
\text { Isak (عشاء) }\end{array}$ & \\
\hline
\end{tabular}

10) Fonem ص

Fonem / / dalam bahasa ditulis dengan /s/. Melalui contoh berikut ini akan terlihat penyerapan kata yang mengandung fonem

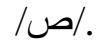

\begin{tabular}{|l|l|l|}
\hline Posisi Awal & Tengah & Akhir \\
\hline
\end{tabular}




\begin{tabular}{|l|l|l|}
\hline & Musala (مصلي) & \\
Nasiaik (نصيحة) & \\
Pasiah (فصيح) & \\
\hline
\end{tabular}

Dalam kamus Minangkabau Indonesia yang diterbitkan oleh Pusat Pembinaan dan Pengembangan Bahasa Departemen Pendidikan dan Kebudayaan Jakarta 1985 ditemukan kosakata serapan bahasa dari bahasa Arab yang di dalamnya terdapat fonem ص. Posisi fonem $ص$ terletak di posisi tengah dan ditransliterasikan menjadi /s/ seperti pada kata musala, nasiaik, dan pasiah. Jelas di sini menunjukkan bahwa fonem ص tidak terdapat di dalam bahasa Minang, alhasil ص fonem ini ditranskripkan ke fonem yang mendekati dengan bunyi yang terdapat dalam bahasa Minang yakni /s/.

11) Fonem b

Fonem $b$ merupakan salah satu fonem yang tidak ditranskrip secara khusus ke dalam bahasa bahasa Minangkabau. Fonem ini ditulis sebagaimana fonem $ت$. Melalui contoh berikut ini akan terlihat penyerapan kata yang mengandung fonem $b$ :

\begin{tabular}{|c|c|c|}
\hline Posisi Awal & Tengah & Akhir \\
\hline Talak (طلاق) & Katik (خاطب) & \\
\hline Tawaf (طائف طو اف) & Katubah (خطبة) & \\
\hline Tobaik (طاب) & Pitah (فظرة) & \\
\hline
\end{tabular}

Pada posisi awal, seperti kata talak dan tawaf kita ketahui bahwa fonem b dibaca tho namun dalam kata talak dan tawaf fonem ini berbunyi $t a$, fonem $b$ seolah berubah menjadi $ت$. Demikian pula pada posisi tengah seperti kata katik, katubah, fonem berubah menjadi ت.

12) Fonem b

Fonem b dalam bahasa Arab ditransliterasi seperti fonem د yakni menjadi /d/, penyerapan dari bahasa Arab ke dalam bahasa yang melibatkan fonem $\mathrm{b}$ terdapat dalam contoh berikut:

\begin{tabular}{|l|l|l|}
\hline Posisi Awal & Tengah & Akhir \\
\hline & Mudarat (مضارت) & Haid (حيض) \\
\hline
\end{tabular}

Baik pada posisi awal maupun pada posisi tengah, seperti pada kata mudharat dan haid, fonem / ל / ditranskrip menjadi /d/ sebagaimana fonem /د/ yang juga ditranskrip menjadi /d/.

13) Fonem غ

Fonem $\dot{\varepsilon}$ ditranskripkan menjadi /g/ dalam bahasa. Sebagaimana diketahui daerah artikulasi penyebutan fonem $\dot{\varepsilon}$ ini mendekati daerah artikulasi huruf /g/, perbedaannva bahwa $\dot{\varepsilon}$ diucapkan dengan menyempitkan pangkal lidah, sedangkan fonem $/ g /$ dalam bahasa Indonesia diucapkan dengan agak melonggarkan pangkal lidah. Berikut ini dapat dilihat penyerapan fonem ini: 


\begin{tabular}{|l|l|l|}
\hline Posisi Awal & Tengah & Akhir \\
\hline Gaib (غائب) & & Balig (بالغ) \\
\hline
\end{tabular}

Berdasarkan contoh di atas fonem / $/ \dot{\varepsilon}$ pada posisi awal sebuah kata seperti kata gaib maupun pada posisi akhir seperti kata balig ditranskrip menjadi /g/.

14) Fonem ف

Fonem / ف/ dalam bahasa Arab mempunyai artikulasi yang sama dengan /f/. Namun dalam penyerapannya ke dalam bahasa Minang fonem ini ada yang tetap ditranskrip dengan /f/ dan ada juga dalam beberapa kosakata berubah menjadi /p/ seperti yang dapat dilihat pada data berikut.

\begin{tabular}{|c|c|c|}
\hline Posisi Awal & Tengah & Akhir \\
\hline $\begin{array}{l}\text { Paidah (فائدة) } \\
\text { Pasiah (فصبح) }\end{array}$ & $\begin{array}{l}\text { Kapan (كفن) } 2 \text { (كافر) } \\
\text { Kapia }\end{array}$ & $\begin{array}{l}\text { Arif (طائف طو اف) (طاف) } \\
\text { Tawaf }\end{array}$ \\
\hline
\end{tabular}

Fonem / ف/ dalam bahasa Arab ada yang tetap menjadi fonem /f/ dalam kosakata serapan bahasa Minang seperti kata mufti, uruf dan wakaf. Ada juga yang berubah menjadi /p/ seperti pada kata paidah, pasiah dll.

15) Fonem /k/ s

Fonem $/ k$ / atau kaf dalam bahasa Arab dipertahankan menjadi fonem $/ k /$ dalam penyerapannya ke dalam bahasa Minang.

\begin{tabular}{|c|c|c|}
\hline Posisi Awal & Tengah & Akhir \\
\hline Kalimaik (كلمة) & Barakaik (بركة) & \\
\hline Kapan (كفن) & Hakim (حاكم) & \\
\hline Kapia (كافر) & Maka (مكة) & \\
\hline
\end{tabular}

Seperti yang dapat dilihat pada contoh di atas, fonem /s/ di posisi awal dan tengah tidak mengalami perubahan yakni tetap dituliskan dengan fonem $/ \mathrm{k} /$ yang mempunyai bunyi serupa dengan fonem /5/. Misalnya, pada posisi awal, kalimaik dan kapan, pada posisi tengah, barakaik, hakim.

16) Fonem J

Fonem $J$ dalam bahasa Arab mempunyai artikulasi yang sama dengan huruf $/ l /$. Dalam penyerapannya ke dalam bahasa Minang dapat dilihat seperti pada contoh berikut.

\begin{tabular}{|c|c|c|}
\hline Posisi Awal & Tengah & Akhir \\
\hline Labai (ليبب) & $\begin{array}{l}\text { Alam (عالم) } \\
\text { Alim (عالم) } \\
\text { Almahum (المرحوم) }\end{array}$ & $\begin{array}{l}\text { Amal (عل) (صل) } \\
\text { Asali (بلل) } \\
\text { Bila }\end{array}$ \\
\hline
\end{tabular}

Berdasarkan contoh, terlihat bahwa fonem /1/, baik pada posisi awal, seperti kata /abai/, pada posisi tengah, seperti kata alam dan 
alim, maupun pada posisi akhir, seperti amal dan hal tidak mengalami perubahan dalam penyerapannya. Namun dapat dilihat di posisi akhir adakalanya fonem /l/ menjadi tak terbaca seperti kata /bila/ dan ada pula yang mendapat imbuhan seperti pada kata /asali/.

17) Fonem $?$

Fonem \& dalam bahasa Arab ditranskrip ke dalam huruf $/ \mathrm{m} /$. Penyerapan beberapa kosakata bahasa Minang dari bahasa Arab yang melibatkan fonem ini dapat dilihat pada data berikut.

\begin{tabular}{|c|c|c|}
\hline Posisi Awal & Tengah & Akhir \\
\hline Madrasah (مدرسة) & Almahum (المرحوم) & Alam (عالم) \\
\hline Mahar (مهر) & Amal (عمل) & Alim (عالم) \\
\hline Mahia (ماهر) & Aman (امن) & Almahum (المرحوم) \\
\hline
\end{tabular}

Berdasarkan contoh itu dapat di ketahui bahwa fonem / مان / tetap dipertahankan menjadi fonem $/ \mathrm{m} /$, baik pada posisi awal seperti kata muhrim dan mukim; pada posisi tengah, seperti kata zaman dan umi, maupun pada posisi akhir, seperti kata paham dan kalam.

18) Fonem ن

Fonem i dalam bahasa Arab mempunyai bunyi yang sama dengan /n/. Hal ini dapat terlihat seperti pada data berikut.

\begin{tabular}{|c|c|c|}
\hline Posisi Awal & Tengah & Akhir \\
\hline Nabi (نبي) & $\begin{array}{l}\text { Umanaik (امانة) } \\
\text { Duia (دنازة) } \\
\text { Janazah }\end{array}$ & 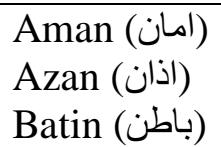 \\
\hline
\end{tabular}

Contoh data memperlihatkan bahwa fonem / أن/ tidak mengalami perubahan, baik pada posisi awal seperti kata nabi; pada posisi tengah, seperti kata janazah dan sunah, maupun pada posisi akhir, seperti kata rukun dan zaman. Akan tetapi pada kata /duial fonem $/ \mathrm{n}$ / dihilangkan atau tidak dibaca secara jelas pada posisi tengah kata.

19) Fonem 9

Fonem 9 dalam bahasa Arab mempunyai kemiripan bunyi dengan huruf /w/. Beberapa kosakata serapan bahasa Minang dari bahasa Arab yang melibatkan fonem ini bisa dilihat dalam data berikut.

\begin{tabular}{|c|c|c|}
\hline Posisi Awal & Tengah & Akhir \\
\hline $\begin{array}{l}\text { Wajib (واجب) } \\
\text { Wahyu (وحي) } \\
\text { Wakaf (وكن) }\end{array}$ & $\begin{array}{l}\text { Arawah } \\
\text { Awa (ارول) } \\
\text { Awa (فتوي) }\end{array}$ & \\
\hline
\end{tabular}

Seperti terlihat pada contoh pertama dan kedua, kata wajib dan wahyu, fonem /w/ pada posisi awal tetap. Demikian pula pada contoh 
kata tawakal, tawaf, dantakwil, fonem /w/ pada posisi tengah tidak rnengalami perubahan. Namun pada kata larawah/, adakalanya diucapkan dengan /aruah/ dengan mengganti fonem /w/ menjadi /u/.

20) Fonem 。

Fonem /o/ dalam bahasa Arab ditranskrip dengan huruf $/ \mathrm{h} /$ serupa dengan fonem / $/$ / tanpa titik di bawahnya. Dalam penyerapan bahasa Minang dari bahasa Arab, beberapa dapat dilihat pada data berikut.

\begin{tabular}{|l|l|l|}
\hline Posisi Awal & Tengah & Akhir \\
\hline & Mahar (مهر) & \\
& Mahia (مكروه) & \\
& Makruh (ماهو) & \\
\hline
\end{tabular}

Berdasarkan data, terlihat fonem ini berada di posisi tengah dan diserap dengan huruf /h/ seperti pada kata mahar dan makruh.

21) Fonem ي

Pada dasamya fonem اي/ memang mempunyai bunyi yang sama dengan/y/. Berdasarkan data, selain fonem /y/ terserap menjadi fonem /y/, juga terlihat penghilangan fonem /y/. Dalam contoh jariah, fonem /y/ pada posisi tengah tidah dibaca. Namun dalam kosakata lain baik pada posisi awal maupun tengah, fonem /y/ tetap disebutkan seperti pada kata /yakin/.

\begin{tabular}{|l|l|l|}
\hline Posisi Awal & Tengah & Akhir \\
\hline Yakin (يقين) & Jariah (جرية) & \\
Yatim (يتية) & Kuliah (كلية) & \\
\hline
\end{tabular}

\subsection{Persamaan Bunyi Kosakata Serapan Bahasa Arab dan Bahasa Minang}

Tabel di bawah merupakan data persamaan bunyi bahasa Minang. Bahasa daerah Sumatera Barat ini yang merupakan rumpun bahasa Melayu menyerap kosakata dari berbagai bahasa termasuk juga menyerap dari bahasa Arab. Cara penyerapannya diantaranya adalah dengan mengambil kosakata tersebut secara utuh yakni menggunakan ejaan dan makna yang sama antara bahasa Arab dan bahasa Minang seperti terlihat pada tabel di bawah ini.

\begin{tabular}{|r|l|l|}
\hline Bahasa Arab & Bahasa Minang & \multicolumn{1}{c|}{ Pengertian } \\
\hline$ن ب ي$ & Nabi & Utusan Allah kepada umat manusia \\
\hline$ر$ & Riba & Mengambil timbangan lebih \\
\hline سبب & sabab & Akibat, alasan \\
\hline
\end{tabular}

\subsection{Kemiripan Bunyi dan Perubahan Bunyi Interpetasinya terhadap Makna dalam Kosakata Serapan Bahasa Minang dari bahasa Arab}


Pada kasus kemiripan bunyi, tentu saja ada perbedaan bunyi antara bahasa yang menyerap dengan yang diserap namun demikian ada kemiripan pada bunyi tersebut. Dalam hal ini bahasa Minang adalah bahasa yang menyerap dari bahasa Arab. Penyerapannya dengan cara: disimilasi, diftongisasi, anaptiksis dan zeroisasi.

1) Disimilasi, adalah perubahan bunyi dari dua bunyi yang sama atau mirip menjadi bunyi yang tidak sama atau berbeda, perubahan yang terjadi pada bahasa Minang yang diserap dari bahasa Arab diantaranya:

a. Bunyi /â/ berubah menjadi bunyi /a/, seperti kata /hâl/ menjadi /hal/

b. Bunyi /‘/ berubah menjadi bunyi / $\mathrm{k} /$, seperti kata /ta'wîl/ menjadi /takwil/ dengan diikuti perubahan / î/ menjadi /i/

c. Bunyi /î/ berubah menjadi bunyi /i/, seperti kata /jîran/ menjadi /jiran/

d. Bunyi /q/ berubah menjadi bunyi /k/, seperti kata /yaqîn/ menjadi /yakin/ dengan perubahan lainnya berupa /î/ menjadi /i/

e. Bunyi /ḍ/ berubah menjadi bunyi /d/, seperti kata /haị̣/ menjadi /haid/

f. Bunyi z berubah menjadi bunyi z, seperti kata /ta'ẓim/ menjadi /takzim/ dengan perubahan $/ \%$ menjadi $/ \mathrm{k} /$

2) Diftongisasi, adalah perubahan bunyi vokal tunggal (monoftong) menjadi dua bunyi vokal atau vokal rangkap (diftong) secara berurutan. Perubahan dari vokal tunggal menjadi vokal rangkap diucapkan masih dalam satu puncak kenyaringan sehingga tetap dalam satu silabe. Diftongisasi dalam bahasa Minang terjadi pada perubahan: Pertama, bunyi /i/ menjadi bunyi /ia/ seperti pada kata /mubaliah, pasiah/. Kedua, bunyi /u/ menjadi bunyi /ua/ seperti pada kata /subuah/. Ketiga, bunyi /a/ berubah menjadi bunyi /ai/ seperti pada kata /barakaik, ibaraik, kalimaik, tamaik, mupakaik/. Keempat, bunyi /u/ menjadi bunyi /ui seperti pada kata /tadaruih, sujuik/.

3) Anaptiksis atau suara bakti, yaitu perubahan bunyi dengan jalan menambahkan bunyi vocal dengan tujuan untuk memperlancar ucapan. Anaptiksis atau penambahan bunyi terdapat juga dalam salah satu pola penyerapan bahasa Minang meliputi penambahan di tengah kata (epentesis) dalam bahasa Minang seperti penambahan bunyi /u/ pada kata /rukun/, bunyi /a/ pada kata /wakatu, fajar, asar, mahar, akad/ merupakan serapan dari bahasa Arab yang awalnya berbunyi /waktu, fajr, asr, mahr, aqd. Selanjutnya ada lagi penambahan bunyi /i/ pada kata /jiin dan kurisi/ yang awalnya berbunyi /jin, kursi/. Sementara untuk protesis (penambahan di awal kata) dan paragog, (penambahan di akhir kata) belum ditemui pada kata serapan bahasa Minang dari bahasa Arab.

4) Zeroisasi, yaitu penghilangan bunyi fonemis sebagai akibat upaya penghematan atau ekonomisasi pengucapan. Peristiwa ini biasa terjadi 
pada penutur bahasa-bahasa di dunia. Zerosiasi diklasifikasi menjadi tiga bagian, yaitu:

a) Aferesis, adalah penghilangan atau penanggalan satu atau lebih fonem pada awal kata. Dalam bahasa yang diserap dari bahasa Arab Penghilangan bunyi tersebut antara lain, penghilangan bunyi /h/ seperti pada /aram, uruf, dan ukum /. Selain itu ditemukan juga penghilangan fonem /a/ pada kata /rabaa/.

b) Sinkop, adalah penghilangan atau penanggalan satu atau lebih fonem pada tengah kata. Dalam bahasa serapan dari bahasa Arab, kasus ini terjadi pada penghilangan bunyi /r/ seperti pada kata /almahum, pitah/. Sementara itu ada juga penghilangan fonem/bunyi /y/ pada kata /sukur, jariah, kuliah, ziarah, sariat/. Berikutnya ada penghilangan fonem /n/ pada kata /duia=dunia/. Selain itu ada juga penghilangan bunyi /h/ pada kata /kawa=kahwal kata ini menyerap dari bahasa Arab yang mempunyai arti /kopi/.

c) Apokop, adalah penghilangan atau penanggalan satu atau lebih fonem pada akhir kata. Dalam bahasa Minang terhadap penghilangan bunyi /r/ seperti pada kata /saba $=$ sabar/. Selain itu juga ada penghilangan bunyi /l/ pada kata /misal=misal/ dan penghilangan bunyi /h/ pada kata /maka=makah/.

\subsection{Kajian Morfologi Serapan Bahasa Minang Dari Bahasa Arab}

Morfologi adalah bagian dari ilmu bahasa yang membicarakan seluk-beluk bentuk kata serta pengaruh perubahan-perubahan bentuk kata terhadap golongan dan arti kata. ${ }^{10}$ Morfologi adalah telaah morfem. Morfem sendiri adalah satuan bentuk bahasa terkecil yang mempunyai makna secara relatif stabil dan tidak dapat dibagi atas bagian bermakna yang lebih kecil. ${ }^{11}$ Bahasa Minangkabau mempunyai empat pola suku kata, yaitu vokal, vokal-konsonan, konsonan-vokal dan konsonan-vokalkonsonan, sebagaimana berikut ini:

1) V (vokal) seperti: a.ka (akal), i.jab (ijab), u.kum (hukum)

2) VK (vokal-konsonan) seperti pada kata 'al.ma.hum' (almahrum)

3) KV (konsonan-vokal) seperti: sa.ba (sabar), mi.sa (misal)

4) KVK (konsonan-vokal-konsonan) seperti: fat.wa (fatwa), hal (perihal)

\section{Analisis Makna}

Semantik secara istilah adalah cabang ilmu bahasa yang mempelajari hubungan antara tanda-tanda dengan hal-hal yang ditandainya, atau dengan kata lain, bidang studi bahasa yang membahas

\footnotetext{
${ }^{10}$ M. Ramlan, Ilmu Bahasa Indonesia: Morfologi, Suatu Tinjauan Deskriptif. U.P. Karyono, Yogyakarta, 1983, hlm. 3

${ }^{11}$ KBBI offline
} 
arti atau makna. ${ }^{12}$ Cakupan semantik hanyalah makna atau arti yang berkenaan dengan bahasa sebagai alat komunikasi verbal. ${ }^{13}$

1) Makna tetap

Makna tetap yang terdapat dalam penelitian ini menginterpretasikan bahwa makna yang diserap dari bahasa Arab oleh bahasa Minang tidak mengalami perubahan atau bisa dikatakan tidak bergeser, sama dengan makna asli pada bahasa sumber.

\begin{tabular}{|l|l|}
\hline Halal (حلال) & $\begin{array}{l}\text { Halal, sah menurut hukum, yang } \\
\text { dibolehkan }\end{array}$ \\
\hline Wajib (حاجب) & $\begin{array}{l}\text { Bila dilakukan berpahala ditinggalkan } \\
\text { berdosa }\end{array}$ \\
\hline Hakim (حاكم) & Hakim, penguasa, pemimpin \\
\hline
\end{tabular}

2) Makna Menyempit

Jenis makna ini terjadi jika makna suatu kata memiliki spesifikasi dari bahasa sumber ketika diserap ke dalam bahasa penerima.

\begin{tabular}{|l|l|}
\hline Fatwa (فنو) & pendapat, nasehat \\
\hline Sunah $(س ن ة)$ & $\begin{array}{l}\text { Sunah nabi, kebiasaan, tradisi, aturan, } \\
\text { norma }\end{array}$ \\
\hline Madrasah (مدرسة) & sekolah, perguruan, madzab, aliran \\
\hline
\end{tabular}

Dalam tabel diatas terdapat beragam makna dari satu kata bahasa Arab, namun dalam menyerap, bahasa Minang tidak menggunakan semua makna yang ada dalam bahasa Arab melainkan hanya menggunakan salah satu dari makna-makna tersebut.

3) Makna Meluas

Makna meluas terjadi pada proses penyerapan kata bahasa Minang dari bahasa Arab yaitu dengan adanya penambahan makna pada bahasa sasaran seperti pada kata 'kalam' dalam bahasa Minang memiliki dua makna, terkadang dipakai untuk makna 'gelap', terkadang juga dipakai untuk 'alat menulis' (قلم= pena).

\section{Kesimpulan}

Pada tataran fonologis kosakata serapan bahasa yang terambil dari bahasa Arab, beberapa fonem bisa diserap secara utuh dalam artian sesuai dengan transliterasi Arab-latin, namun ada juga yang tidak diserap secara utuh seperti fonem $\mathbf{i}$, karena fonem ini bukan diserap dengan menggunakan fonem /f/ dalam bahasa namun diserap dengan /p/.

12 .W.M. Verhaar, Asas-Asas Umum, hlm.13

${ }^{13}$ Abdul Chaer, Pengantar Semantik Bahasa Indonesia; Edisi Revisi, hlm. 2-3 
Dalam tataran morfologis dan dan semantik, beberapa perbedaan ditemukan antara bahasa Arab dan bahasa Minang. Sekalipun kosakata serapan bahasa Minang tersebut diambil dari bahasa Arab, namun urutan huruf dan kata terkadang tidak serupa. Begitu pula mengenai makna kata dalam bahasa Minang yang merupakan serapan dari bahasa Arab mengalami penyempitan dan perluasan, namun tidak sedikit juga yang mempunyai persamaan makna.

\section{Daftar Pustaka}

Amril dan Ermanto. 2007. Fonologi. Bahasa Indonesia. Padang: UNP.

Chaer, Abdul Pengantar Semantik Bahasa Indonesia; Edisi Revisi

Haryanti, Dwi Indonesia. Edisi Februari 2007, Tahun ke 25, Nomor 1. Yayasan Obor Indonesia.

Mackey, William F. 1968, The Description of Billingualism, dalam Joshua A. Fishman (ed), Reading in the Sociology of anguage, The Hauge: Mouton \& Company.

Muslich, Masnur (2008). KTSP Pembelajaran Berbasis Kompetensi dan Kontekstual. Jakarta: Bumi Aksara.

Nasir, Moh. Metode Penelitian, dalam Buletin Al-Turas Mimbar Sejarah,Sastra,Budaya, dan Agama - Vol. XXIII No.2, Juli 2017

Ramlan, M. Ilmu Bahasa Indonesia: Morfologi, Suatu Tinjauan Deskriptif. U.P. Karyono, Yogyakarta.

Surakhmand, Winarno. 1980, Pengantar Penelitian Ilmiah. Bandung: Tarsito.

Sudaryanto. Metode dan Aneka Teknik Analisis Bahasa, 1993, Yogyakarta: Duta Wacana University Press.

Verhaar, W.M. Asas-Asas Umum. 